Yuliia Matvieieva,

Ph.D., Sumy State University, Ukraine

(iD) ORCID ID, 0000-0002-3082-5551

email:y.matvieieva@management.sumdu.edu.ua

Salvin Paul,

Ph.D., Associate Professor, Sikkim University, India

email: spaul@cus.ac.in

Tetiana Honchar,

Sumy State University, Ukraine

Correspondence author: y.matvieieva@management.sumdu.edu.ua

\title{
DEVELOPMENT PROSPECTS OF YOUTH-FRIENDLY CLINICS UNDER HEALTHCARE REFORM
}

Abstract. This article analyzes the preconditions for «youth-friendly» services development. The study aims to justify the development prospects and identify ways to improve the efficiency of the Center for Health and Social Assistance to Children and Youth "Youth-Friendly Clinic» in Shostka under healthcare reform. The object of the study is the Center for Health and Social Assistance to Children and Youth "Youth-Friendly Clinic». The study's subject is the organizational, economic and social relations that arise of the Center for Health and Social Assistance to Children and Youth «Youth-Friendly Clinic» under healthcare reform. The methodological basis of this study is a systematic approach and fundamental premises of the general economic theory. The study involved scientific research methods such as abstract-logical and system-structural analysis to determine the problems leading to the need for "youthfriendly» services; statistical and expert assessments methods to determine the number of visits to the "YouthFriendly Clinic». The research involved data for 2017-2019. The study determined several global problems that caused the emergence and development of youth-friendly clinics as follows: the risk of morbidity of young people through an active lifestyle; low awareness of young people about the importance of maintaining their own health; lack of specialists competent in socio-psychological problems of today's youth. Besides, the findings showed that the main prerequisite for youth-friendly clinic development is achieving sustainable development goals, especially goal 3 «Good health and well-being». This study considered preventive work, voluntary counselling and testing for HIV (VCT), medical-diagnostic and social areas of the Center for Health and Social Assistance to Children and Youth "YouthFriendly Clinic» in Shostka. The authors analyzed the visit dynamic and the share of specialists in-demand among clients of the Center. The most active groups of clients were identified by age and sex. The obtained results allowed identifying the effective management tools of the researched Center, prospects and ways to improve its activity under healthcare reform. The authors indicated further research directions considering the impact of the COVID-19 pandemic on the youth-friendly clinics and the best world practice in the youth clinics management system.

Keywords: health and social assistance, youth-friendly services effectiveness, healthcare reforms, medical services, medical and preventive institutions.

Introduction. The youth is the principal active demographic. Thus, young people's health, development, and comprehensive education is a priority for the government. It stands to mention that young people need services that differ from those provided to adults. Informational and educational activities and handling with adolescents allow solving many problems and reducing risks. Therefore, one of the tasks of adolescent-friendly health clinics under health care reforming is to help youth realize the value of their lives and health and discover their own potential.

It is worth noting that the sustainable development of Ukraine requires population reproduction, achieving the well-being of everyone. Therefore, it is necessary to preserve sexual and reproductive health, which became the basis of the Concept of the National Program «National Integrated Sexual Reproductive Health 2021».

Cite as: Matvieieva, Y., Paul, S., \& Honchar, T. (2020). Development Prospects of Youth-Friendly Clinics under Healthcare Reform. Health Economics and Management Review, 2, 33-42. http://doi.org/10.21272/hem.2020.2-04 
The basis of Ukraine's policy in population reproductive health-preserving and maintenance is the Agenda of the International Conference on Population and Development, the UN Millennium Development Goals (2000-2015), the Sustainable Development Plan and Goals (2016-2030). Since 1995, Ukraine has developed and implemented national programs to reduce maternal and infant mortality, adolescent pregnancy, and abortion by providing universal access to quality reproductive health services. Thus, these measures contributed to the achievement of the UN Millennium Development Goals in Ukraine.

The relevance of this study under quality medical care to young people is the essence of achieving the Sustainable Development Goal 3 (SDG 3) «Good health and well-being». SDG 3 aims to reduce infant mortality, improve maternal health and action on HIVIAIDS, malaria and other diseases.

The obtained results on the Scopus database states that the outstanding interest in the problems of effective functioning of youth-friendly clinics was formed under modern conditions. Figure 1 indicates the first wave of positive dynamics on publication activity devoted to investigated issues from 2013 to 2017.

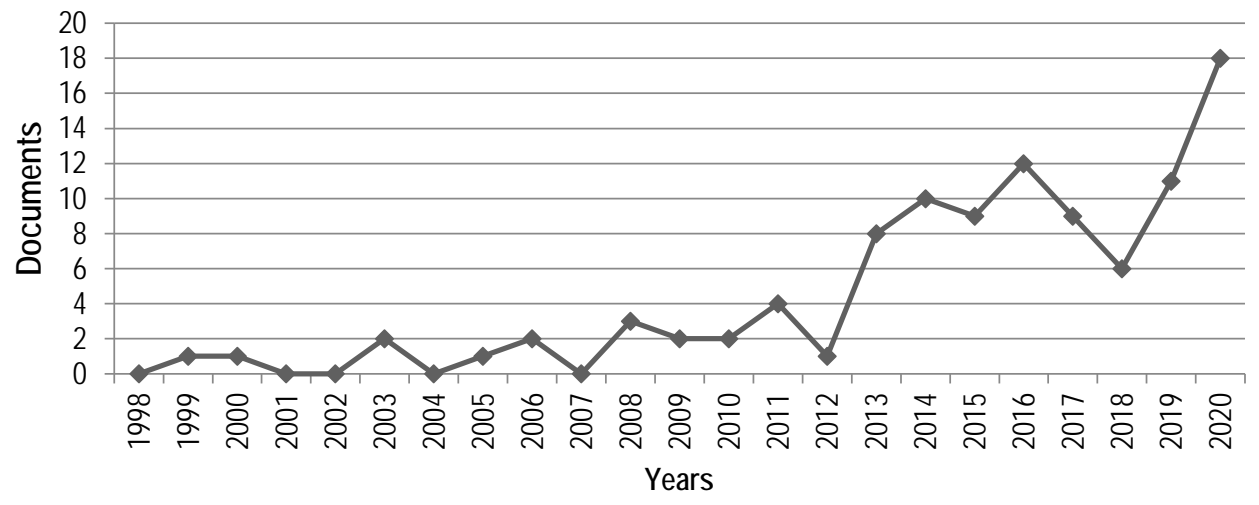

Figure 1. No. of documents in the Scopus database under the limitations TITLE-ABS-KEY «youthfriendly» AND «clinics» for 1998-2020

Source: developed by the authors based on the Scopus database.

Literature Review. Nowadays, the issues on quality medical services for young people are investigated nationally and internationally. Moreover, according to the Scopus database, the most productive scientists are from United States, South Africa, Sweden, United Kingdom, Canada, Kenya, Netherlands, Australia, and Switzerland.

Notably, the scholars abroad such as Bekker L. G., Goicolea I., Christianson M., Hurtig A. K., Sandstrom E., Waenerlund A.K., Wiklund M., Agwu A. L., Allen M. substantially contributed to investigating the issues on providing young people with medical services.

In turn, Van Pinxteren M., Cooper S., Colvin C. J. Feng N., Jin X., Wu J., Wang L., investigated the barriers and opportunities of information on health under providing of effective medical policy (Van Pinxteren et al., 2021).

On the other hand, the scholars such as Clark T. C, Lucassen M. F., Bullen P., Denny S. J., Fleming T. M., Robinson E. M. (Clark et al., 2014), Songtaweesin W. N., Kawichai S., Phanuphak N., Chanachon P., Pondet C. (Songtaweesin et al., 2020) devoted their studies to tolerance in providing quality medicine for young people.

The friendliness of young people to youth clinics are investigated by the scholars as follows: Waenerlund A. K., San Sebastian M., Hurtig A. K., Christianson M., Goicolea I. Besides, the issues on 
forming design services for young people with psychological health problems were studied by Wang A., Tobon J. I., Bieling P., Colvin E., Zipursky R. B.

The pool of researchers such as Seu M., Lopez D., Nave M., Ureta E., Equils O. (Seu et al., 2020), Westberg K. H., Nygren J. M., Nyholm M., Carlsson I. M., Svedberg P. estimated the managers' awareness on the psychological health in the youth-friendly clinics. Thomée S., Malm D., Christianson M., Waenerlund A. K., Goicolea I., studied the challenges and strategies for maintaining youth-friendly health services. The scientists Huaynoca S., Svanemyr J., Chandra-Mouli V. C., Moreno Lopez D., investigated the best practice regarding expanding the youth-friendly model of health care protection.

It stands to mention that studying the problems of effective youth-friendly clinics functioning allows highlighting such key aspects as cost analysis of youth clinics, features of communication between youth clinics and teenagers, prerequisites for establishing a clinic for youth in rural areas, especially working with young people with various diseases. Moreover, the scientists take an interest in studying the issues of investment in the health of the future population by implementing youth programs.

Methodology and research methods. The methodological basis of this study is a systematic approach and fundamental premises of the general economic theory. The study involved scientific research methods such as abstract-logical and system-structural analysis to determine the problems leading to the need for «youth-friendly» services; statistical and expert assessments methods to determine the number of visits to the «Youth-Friendly Clinic». The research was conducted on real data provided by the Center for Health and Social Assistance to Children and Youth «Youth Friendly Clinic» in Shostka. Data analysis covers the research for 2017-2019. This study indicates further research directions considering the impact of the COVID-19 pandemic on the youth-friendly clinics and the best world practice in the youth clinics management system.

Results. Nowadays, ensuring an effective system of functioning of youth-friendly clinics is one of the most important problems in health management caused by the need to implement existing sustainable development goals.

The obtained results on the analysis of the publication activity on the incidence of illnesses in the population showed several problems preceding the development of youth-friendly clinics. Thus, these are:

- lack of provision of information to the public concerning HIV prevention and treatment that results in insufficient awareness of HIV prevention;

_ insignificant motivation for safe sexual behaviour and HIV testing that leads to the growth of genital tract infection cases;

- the risk of reducing the succession and incessancy of preventive measures and the «losing customers» due to minimizing or cutting off of funding for these services, which could lead to a significant deterioration of the epidemic situation;

- the lack of planned state funding for the prevention of sexual transmission of HIV (purchase of condoms for free distribution both in and outside health care facilities among at-risk groups and public) is one of the reasons of HIV spreading through sexual transmission;

- insufficiently developed institutions network HIV testing, especially in rural areas;

- insufficient training quality of the medical staff.

It stands to mention that Ukraine is one of the leaders in the number of HIV-infected in the WHO European Region. As a member of the United Nations, Ukraine has joined the global process of achieving the Sustainable Development Goals by creating national strategic goals. Herewith, the abortion of the HIVIAIDS epidemic due to using the latest practices and treatment methods (a national progress indicator is the number of patients diagnosed with emergence HIV per 100000 population) is considered one of the most important goals. Moreover, to perform this task, Ukraine joined the political declaration on HIVIAIDS «Fast-track: Fight against HIV and End the AIDS Epidemic by 2030», adopted by the UN General Assembly in June 2016. This strategy provides several measures to provide HIV prevention services to 
$90 \%$ of people from key groups on HIV infection, provide medical care to $90 \%$ of people living with HIV, prescribe antiretroviral therapy to $90 \%$ of them and get an indeterminate level of viral load of HIV $90 \%$ of those PLHIV treated with antiretroviral drugs. Therefore, it will help stop the HIV epidemic in the country, prevent new cases of HIV infection, reduce mortality from HIV-related diseases, and enable people with HIV to live a full-on life (Ministerial decree, 2018).

Preservation of sexual and reproductive health is essential for population reproduction, achievement of each person's well-being, and sustainable development in Ukraine. Notably, it forms the basis of the Concept of the National Program «National Integrated Sexual Reproductive Health 2021». Ukrainian policy in preserving and maintaining the reproductive population health is ensured with the Agenda of the International Conference on Population and Development, the UN Millennium Development Goals (20002015), the Sustainable Development Plan and Goals (2016-2030). Besides, since 1995, Ukraine has developed and implemented national programs providing universal access to quality reproductive health services to reduce maternal and infant mortality, adolescent pregnancy, and abortion. Consequently, these measures resulted in achieving the UN Millennium Development Goals in Ukraine.

In turn, there are several problems in reproductive health care as follows:

- growth of depopulation processes;

- inadequate observation of certain reproductive rights of the population;

- lack of state policy and effective children's education system and adolescents on reproductive health;

- high maternal and infant mortality;

- complications in pregnancy and childbirth;

- the spread of sexually transmitted infections, including HIVIAIDS;

- rise in the oncological incidences of the reproductive system;

- men and women infertility;

- access restriction to modern family planning methods.

It worth mentioning the following «youth-friendly» principles recommended by UN Children's Fund and WHO 2002 (Analysis, 2018):

- accessibility - simplifying the application procedure, maximizing the relevance of work schedule to the young people needs, providing free and comprehensive services, etc.;

- voluntariness - informing, involving and developing motivation for the self-conscious application of young people for services;

- friendliness - providing services to young people while understanding and accepting the age characteristics of the target group, tolerance, respect, confidentiality, support in expressing one's own opinion and non-judgmental attitude towards service users.

Preventing the spread of HIVIAIDS is possible by increasing the level of preventive education of adolescents. Thus, the need to provide information and medical care to adolescents caused the development of youth-friendly services.

It stands to note that the first preventive services to adolescents appeared in the United States in 1972. In turn, similar forms of work occurred in 1993 in Sweden, England and other European countries. Institutions providing services to adolescents and young people on the principles of «friendly approach» are established and operate in Ukraine, Belarus, Kazakhstan, Moldova and others.

Notably, the launching "Youth-Friendly Clinics» is accompanied by slow development, objective difficulties, mistakes, and often misunderstanding by managers.

In 1997, the UN Children's Fund and the Government of Ukraine started cooperation. Therefore, to implement modern approaches to providing medical care to adolescents, UNICEF's support, the first youth-friendly clinic (YFC) was established at the Children's Clinical Hospital No. 6 in Shevchenkivskyi 
district of Kyiv in 1998. Herewith, the Ministry of Health of Ukraine supported the YFC establishment. In turn, in 2005-2006, powered by UNICEF under the pilot project, the first YFCs were launched in nine regions of Ukraine (Kyiv, Sevastopol, Odesa, Donetsk, Lviv, Zaporizhia, Poltava, Khmelnytsky and Chernihiv). The spreading of the YFCs aimed to find more and more supporters among health care providers and social workers. Besides, the local executive supported the initiation to launch many YFCs (Ministerial decree, 2018).

In 2006, the methodological and organizational monitoring centre at NDSL «OKHMATDIT» was set up to coordinate, monitor, and methodologically support the centres (departments) of health and social assistance for children and youth «Youth-friendly Clinic» and Action centres for breastfeeding «Childfriendly Hospital». Moreover, the information and resource training centres were launched in Kyiv and Sevastopol.

It is worth mentioning the centre for health and social care to children and youth «Youth-Friendly Clinic» (established in 2007 in Shostka of Sumy region) is an example of a clinic successfully focused on youth-friendly services.

In 2009, the YFC in Shostka was denned as a pilot clinic for practical application counselling and testing for HIV (VCT). The clinic medical personnel trained in seminars-trainings on self-imposed counselling and testing for HIV (VCT). In November 2009, the Coordination Council of the Ministry of Health of Ukraine assigned a status of «Youth-Friendly Clinic» for the Center for Health and Social Assistance to Children and Youth. The institution was rated 98.5\% (the highest among YFCs in Ukraine). In October 2012, the Center was reevaluated for compliance with the status of «Youth-Friendly Clinic» (99.1\% of positive eligibility according to the 10 Interim Standards).

The medical personnel of the Shostka YFC is a team of enthusiastic, caring people who understand adolescent characteristics. The staff shows professionalism, tolerance, adheres to the principles of anonymity and confidentiality.

The YFC «friendly approach» is based on the principles of accessibility, friendliness, voluntariness. Adolescents and young people, regardless of national, religious and gender differences, place of residence and social status, have equal access to services (Order of the Ministry, 2010).

YFC employees are friendly to young people, understand adolescent characteristics, respect the problems of visitors. Counselling is moral and tolerant. The medical specialists are competent in the legal aspects of medical and social services for visitors informing them on voluntary consent.

The analysis of statistical data on the activities of YFC in Shostka showed that 4157 visitors were received in 2019. Compared to 2017 and 2018, this indicator is stable (in 2017 - 4258 visitors; in 2018 4097 visitors). Herewith, the main YFC performance ratio is the percentage of revisits. Table 1 demonstrates that in 2019 , this indicator was $60 \%$, which met the temporary standards - above $50 \%$.

Table 2 showed that in 2019, most clients sought medical advice of obstetrician-gynaecologist $38.3 \%$, dermatovenerologist $-15.3 \%$, psychologist $-17.3 \%$.

Under the age structure of YFC clients, in 2019, most of the visitors were adolescents from 14 to 18 years (the main target group) $-42.0 \%$, while in $2019-37.9 \%$, and $2017-41.7 \%$. In turn, the age group up to 10 years and older than 24 years (others) was $28.7 \%$ in $2019,29.5 \%$ - in 2018 , and $22.2 \%$ - in 2017. Table 3 indicates that the girls are more likely to visit YFC because they care about their health more than the boys. The number of references to a doctor from village visitors during 2017-2019 was almost the same. Besides, in 2019, 92.8\% of YFC clients were city residents. The share of the rural population among YFC clients is $7.2 \%$. Therefore, to increase the number of visitors from the village, it is essential to improve the information work on YFC activities among rural youth (Table 4).

Table 5 demonstrates that in 2019, most customers (87.1\%) applied to the YFC self-imposed. Thus, it indicates sufficient awareness of the target group and the benefits of health and social care. In turn, this 
indicator is stable compared to 2017 and 2018. Visitors also turn to YFC on the advice of teachers, psychologists, specialists of the Department of Family, Children, and Adolescents Services. Thus, it emphasized effective cooperation with other institutions (Analytical report, 2008).

Table 1. The number of visits of Health and Social Assistance Centre «Youth-friendly Clinic» in Shostka

\begin{tabular}{|c|c|c|c|c|c|c|c|c|c|c|c|c|}
\hline \multirow{3}{*}{$\begin{array}{l}\text { Indicat } \\
\text { ors }\end{array}$} & \multicolumn{4}{|c|}{2017} & \multicolumn{4}{|c|}{2018} & \multicolumn{4}{|c|}{2019} \\
\hline & \multicolumn{2}{|c|}{ YFC of Ukraine } & \multicolumn{2}{|c|}{ YFC in Shostka } & \multicolumn{2}{|c|}{ YFC of Ukraine } & \multicolumn{2}{|c|}{ YFC in Shostka } & \multicolumn{2}{|c|}{ YFC of Ukraine } & \multicolumn{2}{|c|}{ YFC in Shostka } \\
\hline & abs & $\%$ & abs & $\%$ & abs & $\%$ & abs & $\%$ & abs & $\%$ & abs & $\%$ \\
\hline Primary & 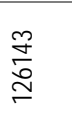 & 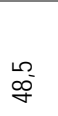 & $\underset{-1}{\stackrel{\nabla}{\sigma}}$ & 吕 & $\begin{array}{l}\mathscr{\Re} \\
\stackrel{0}{0} \\
\stackrel{\leftrightarrow}{\sim}\end{array}$ & $\stackrel{\mathscr{\sigma}}{\mathcal{F}}$ & $\begin{array}{l}\stackrel{\sim}{\sim} \\
\stackrel{\sim}{\sim}\end{array}$ & $\stackrel{m}{m}$ & 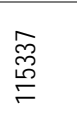 & $\begin{array}{l}\stackrel{\circ}{f} \\
\text { F }\end{array}$ & ్ֶర & 음 \\
\hline \multicolumn{13}{|l|}{ boys } \\
\hline & 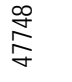 & న্ & 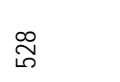 & స̃ & $\stackrel{\mathscr{m}}{\mathscr{ஜ}}$ & $\begin{array}{l}\infty \\
\dot{m}\end{array}$ & 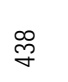 & 罍 & 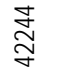 & $\begin{array}{c}0 \\
\dot{m}\end{array}$ & 옹 & 吕 \\
\hline \multicolumn{13}{|l|}{ girls } \\
\hline & 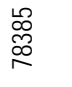 & $\stackrel{-1}{\widetilde{\sigma}}$ & $\stackrel{\circ}{\circ}$ & $\stackrel{m}{0}$ & సิ & $\stackrel{\sim}{\tilde{0}}$ & 용 & $\stackrel{m}{i}$ & ஜ্ণি & $\stackrel{\forall}{\dddot{0}}$ & 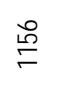 & ำ \\
\hline $\begin{array}{l}\text { Revisit } \\
\text { S }\end{array}$ & ণ্ল్లి & $\frac{1}{n}$ & 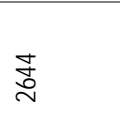 & $\stackrel{\vec{\sigma}}{\widetilde{0}}$ & $\begin{array}{l}\mathscr{\infty} \\
\text { on } \\
\text { o్ } \\
\stackrel{్}{\sim}\end{array}$ & ָั & 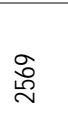 & సิ & ஜ্ণి & 임 & 夺 & 응 \\
\hline boys & 号 & $\stackrel{\text { ల్ }}{\text { mे }}$ & 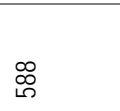 & $\tilde{N}$ & ণ & $\stackrel{\infty}{-i}$ & 望 & $\stackrel{n}{\sim}$ & $\begin{array}{l}\text { ڤ్ } \\
\text { Oे }\end{array}$ & $\begin{array}{l}\text { ঞ্ } \\
\text { চ) }\end{array}$ & ్ํำ & $\begin{array}{l}\stackrel{\circ}{\circ} \\
\stackrel{\sim}{*}\end{array}$ \\
\hline girls & 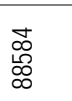 & 덩 & 怘 & $\stackrel{\infty}{N}$ & 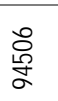 & $\begin{array}{l}\tilde{y} \\
\infty \\
\infty\end{array}$ & $\stackrel{\circ}{\circ}$ & $\begin{array}{l}L^{2} \\
\text { Do }\end{array}$ & $\begin{array}{l}\mathscr{1} \\
\stackrel{\infty}{\circ}\end{array}$ & 궁 & $\underset{⿱}{\stackrel{+}{\sigma}}$ & 함 \\
\hline Totally & & & 4258 & & & & & & & & & \\
\hline
\end{tabular}

Table 2. The number of visits of Health and Social Assistance Centre «Youth-friendly Clinic» in Shostka (by experts)

\begin{tabular}{|l|c|c|c|c|c|c|}
\hline \multirow{2}{*}{ Indicators } & \multicolumn{2}{|c|}{2017} & \multicolumn{2}{c|}{2018} & \multicolumn{2}{c|}{2019} \\
\cline { 2 - 6 } & abs & $\%$ & abs & $\%$ & abs & $\%$ \\
\hline Total number of turns to the YFC experts, where: & 4258 & 100 & 4097 & 100 & 4157 & 100 \\
\hline 1.1. Including the number of references to a doctor, where: & 3446 & 80,9 & 3322 & 81,1 & 3417 & 82,2 \\
\hline paediatrist & 345 & 8,1 & 406 & 9,9 & 341 & 8,2 \\
\hline obstetrician-gynaecologist & 1630 & 38,3 & 1573 & 38,4 & 1590 & 38,3 \\
\hline dermatovenerologist & 572 & 13,4 & 385 & 9,4 & 638 & 15,3 \\
\hline urologist & 295 & 6,9 & 270 & 6,6 & 268 & 6,4 \\
\hline narcologist & 604 & 14,2 & 688 & 16,8 & 580 & 14,0 \\
\hline $\begin{array}{l}\text { 1.2. Other specialists: } \\
\text { - applied psychologist }\end{array}$ & 789 & 18,5 & 756 & 18,5 & 718 & 17,3 \\
\hline lawer & 7 & 0,2 & 6 & 0,1 & 6 & 0,1 \\
\hline social worker & 16 & 0,4 & 13 & 0,3 & 16 & 0,4 \\
\hline
\end{tabular}

Sources: developed by the authors based on (Analysis, 2017; Analysis, 2018; Analysis, 2019). 
Table 3. The number of visits of Health and Social Assistance Centre «Youth-friendly Clinic» in Shostka (by age and sex)

\begin{tabular}{|l|c|c|c|c|c|c|}
\hline \multirow{2}{*}{ Age and sex of visitors } & \multicolumn{3}{|c|}{ Number of visitors } \\
\cline { 2 - 7 } & \multicolumn{2}{|c|}{2017} & \multicolumn{2}{|c|}{2018} & \multicolumn{2}{c|}{2019} \\
\cline { 2 - 7 } & abs & $\%$ & abs & $\%$ & abs & $\%$ \\
\hline 10 -14 & 532 & 12,5 & 652 & 15,9 & 607 & 14,6 \\
\hline - boys & 239 & 5,6 & 279 & 6,8 & 272 & 6,5 \\
\hline - girls & 293 & 6,9 & 373 & 9,1 & 335 & 8,1 \\
\hline $14-18$ & 1776 & 41,7 & 1553 & 37,9 & 1744 & 42,0 \\
\hline - boys & 541 & 12,7 & 451 & 11,0 & 515 & 12,4 \\
\hline - girls & 1235 & 29,0 & 1102 & 26,9 & 1229 & 29,6 \\
\hline $18-24$ & 1005 & 23,6 & 684 & 16,7 & 612 & 14,7 \\
\hline - boys & 336 & 7,9 & 94 & 2,3 & 100 & 2,4 \\
\hline - girls & 669 & 15,7 & 590 & 14,4 & 512 & 12,3 \\
\hline Other & 945 & 22,2 & 1208 & 29,5 & 1194 & 28,7 \\
\hline - men & 136 & 3,2 & 188 & 4,6 & 170 & 4,1 \\
\hline -women & 809 & 19,0 & 1020 & 24,9 & 1024 & 24,6 \\
\hline Totally & 4258 & 100 & 4097 & 100 & 4157 & 100 \\
\hline
\end{tabular}

Sources: developed by the authors based on (Analysis, 2017; Analysis, 2018; Analysis, 2019).

Table 4. The number of visits of Health and Social Assistance Centre «Youth-friendly Clinic» in Shostka (by place of residency)

\begin{tabular}{|l|c|c|c|c|c|c|}
\hline \multirow{2}{*}{ Place of residency } & \multicolumn{9}{|c|}{ Number of visitors } \\
\cline { 2 - 7 } & \multicolumn{2}{|c|}{2017} & \multicolumn{2}{c|}{2018} & \multicolumn{2}{c|}{2019} \\
\cline { 2 - 7 } & abs & $\%$ & abs & $\%$ & abs & $\%$ \\
\hline city & 3994 & 93,8 & 3814 & 93,1 & 3856 & 92,8 \\
\hline village & 264 & 6,2 & 283 & 6,9 & 301 & 7,2 \\
\hline Totally & 4258 & 100 & 4097 & 100 & 4157 & 100 \\
\hline
\end{tabular}

Sources: developed by the authors based on (Analysis, 2017; Analysis, 2018; Analysis, 2019).

Table 5. Visitors' Referrals

\begin{tabular}{|l|c|c|c|c|c|c|}
\hline \multirow{2}{*}{ Institution name } & \multicolumn{4}{c|}{ Number of visitors } \\
\cline { 2 - 7 } & \multicolumn{2}{|c|}{2017} & \multicolumn{2}{c|}{2018} & \multicolumn{2}{c|}{2019} \\
\cline { 2 - 7 } & abs & $\%$ & abs & $\%$ & abs & $\%$ \\
\hline Self-imposed & 3816 & 89,5 & 3559 & 86,9 & 3620 & 87,1 \\
\hline Specialist of medical and preventive institutions & 181 & 4,3 & 266 & 6,5 & 248 & 6,0 \\
\hline Specialist of education institutions & 96 & 2,3 & 119 & 2,9 & 93 & 2,2 \\
\hline $\begin{array}{l}\text { Specialist of the Department of Family, Children, } \\
\text { and Adolecents Services }\end{array}$ & 50 & 1,2 & 49 & 1,2 & 43 & 1,0 \\
\hline Others & 115 & 2,7 & 104 & 2,5 & 153 & 3,7 \\
\hline Totally & 4258 & 100 & 4097 & 100 & 4157 & 100 \\
\hline
\end{tabular}

Sources: developed by the authors based on (Analysis, 2017; Analysis, 2018; Analysis, 2019).

It is worth emphasizing that prevention to preserve adolescents and young people health is one of the YFC priorities. In turn, the Center for Health and Social Assistance to Children and Youth «Youth-Friendly Clinic» meets several main tasks as follows:

- providing knowledge and developing skills and abilities on responsible behaviour regarding all components of health (physical, mental, social and spiritual) with an increased focus on reproductive health;

- prevention or withdrawal from smoking, drugs and alcohol will prevent the risky behaviour and reduce the impact of its consequences; 
- prevention of sexually transmitted infections, including HIVIAIDS;

- preparation for future parenthood and preservation of reproductive health;

- promoting responsible behaviour in the sexual and interpersonal relationship among adolescents and young people.

Group preventive activity for adolescents, young people and their parents is carried out by YFC and organized groups (secondary schools, vocational schools, boarding school, regional centre for social and psychological rehabilitation of children).

Herewith, it was found that training and conversation are the most effective instrument of group prevention activity. The statistical data showed that in 2019, individual forms of preventive activity covered a significant part of clients (90\%), remaining at the same level of 2017 and 2018. Table 6 shows that the interactive methods (including training and conversation) dominated in group forms of information and educational activity.

Since 2015 YFC of Shostka has participated in the project «Online Prevention». YFC specialists provide online consulting services to visitors of the youth site tennsLIVE (teenslive.info) voluntarily. The Charitable Foundation «Women's Health and Family Planning» in cooperation with the UNESCO Institute for Information Technologies in Education created the tennsLIVE website to improve the access of adolescents and young people to comprehensive information on sexual and reproductive health, motivation for safe behaviour, STI and HIV prevention.

Table 6. Preventive maintenance of the Center for Health and Social Assistance to Children and Youth "Youth-Friendly Clinic» of Shostka

\begin{tabular}{|c|c|c|c|c|c|c|}
\hline Type of activity & \multicolumn{2}{|c|}{2017} & \multicolumn{2}{c|}{2018} & & 2019 \\
\hline & amount & covered & amount & covered & amount & covered \\
\hline Individual forms & 3832 & $90 \%$ & 3687 & $90 \%$ & 3741 & $90 \%$ \\
\hline Group forms, totally & 156 & 3944 & 153 & 4005 & 168 & 4045 \\
\hline Including: & & & & & & 557 \\
\hline Conversations & 43 & 592 & 41 & 498 & 34 & 1779 \\
\hline Trainings & 89 & 1305 & 90 & 1311 & 115 & 124 \\
\hline Round tables & 6 & 188 & 2 & 34 & 5 & 903 \\
\hline Lectures & 9 & 737 & 13 & 493 & 10 & 682 \\
\hline Events & 9 & 1122 & 7 & 1669 & 4 & - \\
\hline Others & - & - & - & - & - & \\
\hline
\end{tabular}

Sources: developed by the authors based on (Analysis, 2017; Analysis, 2018; Analysis, 2019).

The obtained results showed that 134500 new users visited the website in 2019. Herewith, they covered Ukraine and CIS countries (Belarus, Moldova, Kazakhstan, etc.). In the context of cooperation with the Charitable Foundation «Women's Health and Family Planning», YFC of Shostka has provided several free information materials on disease prevention for YFC clients, which included adolescents and young people.

To determine the institution's priorities, in April 2020, the electronic health care system eHealth was introduced. Its base is a financial management system providing the exchange of medical information and implementing medical guarantee programs.

The YFC follows developed directions to provide the maximal efficiency of medical personnel performance, minimizing time expenditure. Thus, these directions are as follows:

- implementing temporary medical care standards for adolescents and young people;

- developing an algorithm for providing health and social assistance to children and youth in the Center for Health and Social Assistance to Children and Youth «Youth-friendly clinic»; 
- creating the client redirection scheme to other institutions in the provision of health and social services to adolescents and youth in the Center for Health and Social Assistance to Children and Youth «Youth-friendly clinic»;

- developing institution register assisting adolescents and youth;

- mastering the methodology of voluntary pre-and post-test counselling for HIV testing;

- introducing biomaterial research (serum, blood) for the antibodies presence to HIV using rapid tests;

- improving the work performance and efficient planning of the working day in YFC through using technical devices as follows: computer (Internet access available), scanner, copier, printer, telephone, fax, multimedia projector, multimedia screen.

Conclusions. Nowadays, the development of youth-friendly clinics is a precondition for safe and sustainable human existence. Thus, adolescent awareness could reduce the disease risk. A forehanded visit to the highly trusted clinic, which has an emotionally positive clients' attitude, could quickly overcome health problems. Besides, YFC, scientific discoveries and HIV treatment advance provided new diagnostic test systems, medicinal preparation, innovative service delivery models, radically reducing treatment costs. Therefore, there is a world tendency to reduce the new HIV cases.

In turn, the YFC aimed at adhering to gender equality principles in reproductive health. Notably, nowadays, the general system of service provision is focused mainly on women problems, causing the lack of men involving in the problems of family planning and reproductive health. Therefore, the current reformed reproductive health care system should cover both sexes' needs and characteristics. The «friendly approach» in providing reproductive and sexual health services to adolescents and young people will enhance prevention, quality diagnosis and timely treatment (Analysis, 2017).

In turn, effective YFC activities reduce maternal mortality, perinatal and infant mortality, abortion, adolescent pregnancy and abortion among adolescent girls. Besides, YFC focuses on increasing contraceptive use, screening tests for early diagnosis of cervical cancer and breast cancer, etc.

It stands to note that the main goal of YFC is to preserve reproductive health, HIVIAIDS prevention and responsible behaviour among adolescents and young people regarding their own health. Therefore, proper financing «Youth-Friendly Clinics» in the health care system will provide services to key groups: people living with HIV, adolescents and young people under health care reform.

The systematization of scientific background allowed concluding that most researchers emphasized that developing of YFCs' effective system required involving the professional design services; introducing and developing mobile technologies; attracting professionals who can work with today's teenagers; active promoting public awareness; researching and implementing the best foreign practices; assessing the level of friendliness of young people to youth clinics; etc.

Author Contributions: conceptualization, Y.M. and S. P.; methodology, T. H.; software, Y. M.; validation, Y.M., S.P. and T. H.; formal analysis, Y. M.; investigation, S. P.; resources, T. H.; data curation, Y. M.; writing-original draft preparation, S. P.; writing-review and editing, T. H.; visualization, Y. M.; supervision, S. P.; project administration, T. H.; funding acquisition, Y. M.

Funding: This research received no external funding.

\section{References}

Analysis of the activities of centres, departments, offices of medical care for adolescents and youth «Youth-Friendly Clinics» of Ukraine 2018.

Analysis of the activities of centres, departments, offices of medical care for adolescents and youth «Youth-Friendly Clinics» of Ukraine 2017.

Analysis of the activities of centres, departments, offices of medical care for adolescents and youth «Youth-Friendly Clinics» of Ukraine 2019.

Analytical report. Evaluation of youth-friendly clinics, Kyiv, 2008. 
Clark, T. C., Lucassen, M. F., Bullen, P., Denny, S. J., Fleming, T. M., Robinson, E. M., \& Rossen, F. V. (2014). The health and well-being of transgender high school students: results from the New Zealand adolescent health survey (Youth'12). Journal of Adolescent Health, 55(1), 93-99. [Google Scholar] [CrossRef]

European strategy «Health and development of children and adolescents» 2015-2020. Retrieved from [Link]

General remarks № 20 (2016) on the realization of the rights of the child in adolescence. Retrieved from [Link]

Ministerial decree Order of the Ministry of Health of Ukraine № 2379 dated December 21, 2018 «On the establishment of the Permanent Working Group of the Ministry of Health for Cooperation with Adolescents and Youth in the Field of Health Care».

National HIV Testing Strategy in Ukraine: 2019-2030. Retrieved from [Link]

Order of the Cabinet of Ministers of December 27, 2017 № 1018-r «On approval of the Concept of mental health development in Ukraine for the period up to 2030». Retrieved from [Link]

Order of the Ministry of Health of Ukraine № 2379 dated December 21, 2018 «On the establishment of the Permanent Working Group of the Ministry of Health for Cooperation with Adolescents and Youth in the Field of Health Care».

Order of the Ministry of Health of Ukraine № 388 dated 11.05.2010 «On improving the diagnosis of HIV infection».

Resolution of the conference «Adolescents in Ukraine: rights, needs and implementation of the General Comment № 20 in public policy» April 12, 2018

Seu, M., Lopez, D., Nave, M., Rodriguez, E., Ureta, E., \& Equils, O. (2020). Assessing front office staff awareness on mental health resources at youth friendly clinics in Los Angeles County. Community mental health journal, 1-5. [Google Scholar] [CrossRef]

Songtaweesin, W. N., Kawichai, S., Phanuphak, N., Cressey, T. R., Wongharn, P., Saisaengjan, C., ... \& Pondet, C. (2020). Youth-friendly services and a mobile phone application to promote adherence to pre-exposure prophylaxis among adolescent men who have sex with men and transgender women at-risk for HIV in Thailand: a randomized control trial. Journal of the International AIDS Society, 23, e25564. [Google Scholar] [CrossRef]

The decision of the Coordination Council of the Ministry of Health of Ukraine on the implementation of «youth-friendly» medical services dated December 21, 2016.

UNAIDS Strategy: Sustainable Development Goals. Retrieved from [Link]

Van Pinxteren, M., Cooper, S., \& Colvin, C. J. (2021). Barriers and opportunities to using health information in policy implementation: The case of adolescent and youth friendly health services in the Western Cape. African Journal of Primary Health Care \& Family Medicine, 13(1), 1-9. [Google Scholar] [CrossRef]

Ю.А. Матвєєва, к.е.н., Сумський державний університет, Україна

C. Паул, Ph.D., Університет Сіккіма, Індія

Т. Гончар, Сумський державний університет, Україна

Перспективи розвитку «Клініки, дружньої до молоді» в умовах медичної реформи

Ця стаття присвячена аналізу проблем, що сприяли виникненню служб «дружніх до молоді». Метою дослідження є обгрунтування перспектив розвитку та визначення шляхів підвищення ефективності діяльності Центру медикосоціальної допомоги дітям і молоді «Клініка, дружня до молоді» в умовах медичної ресрорми м. Шостка. Об'єктом дослідження є діяльність Центру медико-соціальної допомоги дітям і молоді «Клініка, дружня до молоді» в умовах медичної ресрорми. Предметом дослідження є організаційно-економічні та соціальні відносини, що виникають у процесі діяльності Центру медико-соціальної допомоги дітям і молоді «Клініка, дружня до молоді» в умовах медичної реформи. Методологічною базою дослідження є системний підхід, а також фундаментальні положення загальної економічної теорії. Для практичної реалізації застосовано наступні методи наукового дослідження: абстрактно-логічний системно-структурний аналіз - при визначенні проблем що призвели до необхідності виникнення служб «дружніх до молоді»; методи статистичної та експертної оцінок - при визначенні кількості відвідувань «Клініки, дружньої до молоді». Дослідження охоплюють аналіз даних за 2017-2019 роки. У ході дослідження встановлено, що поява та розвиток клінік дружніх до молоді спричинено низкою наступних світових проблем: ризик захворюваності молодого населення через активний спосіб життя; відсутність проінформованості молоді щодо питань вважливості збереження власного здоровя; брак фрахівців, які готові працювати з соціально-психологічними проблемами сучасної молоді. При цьому основною передумовою розвитку клінік дружніх до молоді є реалізація цілей сталого розвитку, зокрема цілі 3 «Міцне здоров'я благополуччя». У роботі досліджено напрямки діяльності Центру медико-соціальної допомоги дітям і молоді «Клініка, дружня до молоді» у м. Шостка, а саме: профрілактичну роботу, добровільне консультування та тестування на ВІЛінфекцію, лікувально-діагностичний та соціальний напрямки роботи. Під час дослідження особливостей діяльност Центру визначено динаміку кількості відвідувань, питому вагу фахівців в загальній чисельності, до яких звертались клієнти. Зокрема виявлена найбільш активна група клієнтів клініки за віковою та статевою ознаками. Визначено інструментарій ефективного управління досліджуваного Центру, а також розглянуті перспективи та запропонован иляхи підвищення ефрективності його діяльності в умовах медичної рефрорми. Напрямками подальших досліджень $\epsilon$ урахування наслідків пандемії COVID-19 на діяльність клінік дружніх до молоді.

Ключові слова: медико-соціальна допомога, ефективність діяльності служб «дружніх до молоді», медичні реформи, медичні послуги, лікувально-профілактичні заклади.

Manuscript received: 22.09 .2020

(C) The author(s) 2020. This article is published with open access at Sumy State University. 